\title{
Buscando al encomendero. Lucas Martínez Vegaso, la administración de la justicia y las redes del poder colonial. Tarapacá, siglo XVI
}

\section{Looking for the encomendero. Lucas Martínez Vegaso, the administration of justice and the networks of colonial power. Tarapacá, 16th century}

Luis Miguel Glave $^{1}$ https://orcid.org/0000-0003-1452-7017

Alberto Díaz Araya ${ }^{2}$ https://orcid.org/0000-0001-5080-1672

${ }^{1}$ Instituto de Estudios Peruanos, Arnaldo Márquez 2277, Jesús María. Lima, PERÚ.

Email: lmglave@hotmail.com

${ }^{2}$ Departamento de Ciencias Históricas y Geográficas, Universidad de Tarapacá. Av. 18 de septiembre 2222. Arica, CHILE. Email: albertodiaz@uta.cl

\section{Resumen}

Basado en un caso muy particular referido al pleito por la gran encomienda de Tarapacá de Lucas Martínez, este artículo describe y analiza las formas que adquirió la lucha por el control de los recursos antes de las grandes reformas de la administración del virrey Toledo y, en relación con ello, el establecimiento del gobierno colonial y la administración de la justicia. Desde una historia local, se llega a las altas esferas del poder virreinal en la década de 1560 , momento crucial en el devenir del orden del reino en el futuro. El contexto del estudio son los pormenores de la visita a la Audiencia que se encomendó al comisario Briviesca de Muńatones, caso que sirve de hilo conductor del artículo, que permiten acercarnos a las complejas redes sociales, familiares y económicas de la naciente sociedad colonial.

Palabras claves: encomienda, administración de justicia, visitas, redes de poder, Tarapacá.

\begin{abstract}
Based on a very particular case referring to the dispute for the great entrust of Tarapacá by Lucas Martínez. This article describes and analyzes the forms that the struggle for the control of the resources acquired before the great reforms of the administration of viceroy Toledo and, In connection to this, the establishment of colonial government and the administration of justice. From a local history, it reaches the high spheres of vice royal power in the 1560 s, a turning point in shaping the future order of the kingdom. The context of the study are the details of the Audience's visit to Commissioner Briviesca de Muñatones, a case that serves as the guiding principle of the article, which allows us to approach the complex social, family and economic networks of the emerging colonial society.
\end{abstract}

Keywords: encomienda, administration of justice, visits, networks of power, Tarapacá.

Recibido: 15 diciembre 2016. Aceptado: 30 junio 2017 


\section{Introducción}

En abril de 1561 el escribano Domingo de Agurto, comisionado por el visitador de la Audiencia, Briviesca de Muñatones, se dirigía a las minas de La Cruz en Huantajaya, a legua y media de Ique Ique [Iquique] buscando a Lucas Martínez Vegaso, encomendero de los indios de ese extenso territorio que abarcaba desde el sur de Arequipa hasta los confines de Tarapacá (Bertonio, 1612; Álvarez, 1588 [1998]; Cerrón, 1998; Torero, 2002; Díaz, 2003). ${ }^{1}$ Llevaba una orden conminatoria para que Martínez Vegaso se presentara en Lima ante Muñatones, para prestar declaraciones sobre ciertos hechos que comprometían a oidores y oficiales de la Real Audiencia de Lima.

Tomando como base dicha escena, el propósito de este artículo es analizar, utilizando una serie de expedientes documentales, los pormenores de la búsqueda infructuosa de Agurto al encomendero Martínez Vegaso. Esto nos permite describir cómo funcionaban en un territorio apartado del centro de poder virreinal la economía y la justicia, retratando a ciertos personajes que interactuaron. A partir de allí, detallamos los pleitos judiciales y sociopolíticos entre los encomenderos Lucas Martínez y Jerónimo

1 El antiguo mineral de Huantajaya y el puerto de Iquique se encuentran localizados en la región de Tarapacá en el actual norte de Chile. Las expresiones Ique Ique o hique hique, que derivaron paulatinamente al topónimo de Iquique para referirse a este puerto del sur de la encomienda, en su acepción original se puede encontrar tanto en la cartografía como en las crónicas coloniales. Tradicionalmente suele relacionarse con las expresiones aymaras "ikińiki”, "iquicatatha”, "iquiquipatha”, "iquiraqui", que significaría lugar apto para dormir o descansar ("iquira”: sueño) o "iqui" ("jornada o dormida de camino”), según Bertonio (1612). Sin embargo, consideramos que la voz "ique", de acuerdo a la información de Bartolomé Álvarez (1588), correspondería al "alma", expresión que los indios no sabrían interpretar, o también significaría "padre" o "señor" (asociándose a deidad), y según Cerrón Palomino (1998) y Torero (2002) su origen estaría en la lengua puquina. Otros topónimos del mismo origen en el litoral de Tarapacá son los que tienen la terminación "aya”, como Chanavaya y Huantajaya (Díaz, 2003). Sobre la figura histórica de Lucas Martínez Vegaso, existe un profuso trabajo investigativo de Efraín Trelles Aréstegui (1983), amigo e historiador, a quien dedicamos este artículo. de Villegas; litigios engorrosos que fueron asumidos posteriormente por sus sucesores. La reconstrucción de la escena y el pleito que siguió ilustran la administración de la justicia en el naciente Estado colonial y el complejo entramado de relaciones de poder sociopolítico, familiar y económico sobre el cual este proceso se sustentaba, conectando la encomienda de Tarapacá con un laberinto de redes virreinales vinculadas con la política y justicia imperial.

\section{Los desencadenantes de la escena}

El virrey Andrés Hurtado de Mendoza (conocido como el Marqués de Cañete) había sido cesado de su cargo luego de que se presentaran acusaciones acerca de abusos e irregularidades durante su mandato. Los acusadores procedían de todos los sectores, incluso oidores y oficiales reales. Algunos manifestaron que, abrumado por la censura que su cese significaba, el mandatario falleció en 1560 antes de que llegara su sucesor. Ciertamente, todo este período había sido muy agitado. Ańos antes, el virrey Blasco Núnez Vela (17 mayo 1544 - 18 enero 1546) había muerto en batalla en manos de encomenderos alzados contra la administración real. Gonzalo Pizarro controló desde entonces las principales ciudades y se erigió como gobernador hasta que Pedro de la Gasca logró derrotarlo en 1548. Como el principal problema que desencadenó la guerra fue el reparto de las encomiendas, Gasca redibujó el cuadro de los beneficiarios del principal rubro económico en el territorio recién conquistado. Aunque logró la paz, la mayoría de los actores quedaron descontentos (De la Puente, 1992). El segundo virrey, Antonio de Mendoza (12 septiembre 1551 - 21 julio 1552) falleció antes de cumplir un año de gobierno. Ante la ausencia de la autoridad, fueron los oidores y oficiales de la Audiencia de Lima quienes gobernaron entre 1552 y 1556 . Y aún más, siguieron detentando prestigio durante el gobierno de Andrés Hurtado de Mendoza, que fue el presidente de la Chancillería Real (Hanke, 1978). Pero el poder de aquellos oidores abrió flancos y críticas de opositores, debiendo enfrentar descontentos y alzamientos como el de Francisco Hernández Girón. Así, cuando llegó este virrey, sus desavenencias, intereses encontrados y el enraizamiento con sus redes de poder en las distintas regiones andinas vinieron a sumarse a la manera 
principesca y ambiciosa que el mandatario imprimió a su política (Levillier, 1922). ${ }^{2}$

Posteriormente, arribó Diego López de Zúñiga y Velasco, conde de Nieva (11 febrero 1561 - 19 febrero 1564) acompañado de tres comisarios encargados de resolver el problema de la perpetuidad de las encomiendas. Uno de ellos era el licenciado Briviesca de Muñatones, quien debía realizar una visita a la Audiencia y entrevistar a los funcionarios (Angeli, 2013). De esta manera, Briviesca llegó a Lima en octubre de 1560 y de inmediato echó a andar el programa para la visita, enviando edictos a todas las ciudades e informando a quienes quisieran querellarse contra los funcionarios reales, lo hicieran a partir de 1561. Seguidamente, preparó un pliego de preguntas que versaban sobre la práctica de la justicia y el cumplimiento de la pragmática real, llamando a testificar a los principales miembros de los tribunales y personas implicadas. Asimismo, nombró comisionados para que recorrieran los principales centros económicos y políticos coloniales. De esta forma, se programaron pesquisas en Huamanga, Cusco y Arequipa, siendo comisionado el escribano Luis Flores a partir del 10 de enero de 1561. Flores actuó en Guamanga entre el 24 y el 29 de enero; en Cusco, desde el 7 de febrero hasta el 14 de marzo y en Arequipa a fines del mes. Ese verano, en el camino que une Cusco con Arequipa, Luis Flores se encontró con Domingo de Agurto, otro escribano que trabajaba para Muñatones indagando secretamente sobre prácticas de injusticia en las mismas ciudades visitadas por Flores. ¿Cuáles eran aquellas particularidades y connotaciones de las pesquisas? De acuerdo a los documentos consultados, se trataba de preguntas aplicadas a determinados testigos acerca de temas que en las averiguaciones anteriores no habían sido consignados y/o profundizados, y que describían las acciones de los oficiales y encomenderos. Entonces, Agurto debía buscar en el territorio y localizar a testigos claves para que acudieran con prontitud a Lima ante Muñatones. ${ }^{3}$

2 Levillier (1922) compila la documentación fundamental de la época del gobierno audiencial. Es una pieza literaria e historiográfica con bastantes aciertos, sostenido por evidencia presentada por J. Rivas Agüero, quien prologa suposiciones e intuiciones importantes para futuras investigaciones.

3 La información de la pesquisa en Arequipa y Tarapacá

\section{Las redes políticas del poder regional}

En este contexto, Briviesca de Muñatones requirió que Lucas Martínez Vegaso, encomendero y vecino de Arequipa, se apersonara en Lima para aclarar ciertas denuncias sobre irregularidades en su encomienda. Por tales razones, Domingo de Agurto fue el encargado de ir en su búsqueda de acuerdo al mandato de comparecencia del 28 de enero de 1561, edicto que citaba también a Gómez de Solís y a Alonso de Galleguillos. Como sabemos, Lucas Martínez es un conocido personaje de la historia andina temprana (Trelles, 1983). ${ }^{4}$ Cuando ocurren los hechos que relatamos, llevaba algunos ańos de haber recuperado su encomienda de Tarapacá y otros lugares al sur de Arequipa. Había pasado por momentos de gloria, por extremas situaciones de peligro, por derrotas, por luchas judiciales y políticas, y ahora, se aprestaba a vivir el ocaso de la encomienda como la institución del poder económico del naciente virreinato. Pero antes de adentrarnos en el caso de Martínez, veamos el entramado sociopolítico que involucra a los otros dos testigos, Gómez de Solís y Alonso Galleguillos.

Gómez de Solís era vecino de Arequipa, y al ser citado a declarar, se disculpó exponiendo que estaba enfermo y que debido a su avanzada edad corría peligro su vida si viajaba a Lima. Sabemos que Solís era encomendero de Tapacarí (Presta, 2000) $)^{5}$ y formaba

que comentamos en este artículo y el relato sobre la progresión de la misión de los comisionados en Archivo General de Indias (en adelante AGI) Justicia 471, 1559-1563. Visita hecha a la Audiencia de Lima siendo oidores el doctor Melchor Bravo de Sarabia, el licenciado Diego González de Altamirano, el licenciado Pedro Mercado de Peñalosa, el doctor Gregorio González de Cuenca, el licenciado Francisco Saavedra, el fiscal Juan Bautista Monzón y a los demás ministros de justicia, por el licenciado Diego Briviesca de Muñatones, consejero de Castilla y juez nombrado para este efecto $\left(3^{\circ}\right.$ legajo) 1 pieza.

4 El apellido Vegazo no siempre lo usó el personaje; al principio firmaba como Martín o Martínez. Luego sí ańade el segundo apellido y este aparece de diversas maneras: Begaso, Begazo, Vegaso y Vegazo. En las firmas autógrafas de los documentos que usamos, se pone Vegaso, como lo consignamos aquí.

5 Ver AGI, primera Justicia 475, f. 27v. Sobre Solís y particularmente sobre sus bienes en manos de su viuda 
parte de la lista de los encomenderos deudores de Charcas por cobrar antiguos acuerdos luego de las tasas que se hicieron después del reparto de Gasca (Barnadas, 1973). Dicha deuda y pleito habrían hecho tambalear a uno de los conglomerados de negocios más importantes que se habían creado en torno a una encomienda (Presta, 2000). Su mujer, Luisa de Vivar, residía en Arequipa, donde tenía los bienes que llevó en dote al matrimonio (Presta, 2000, p. 186). Paralelamente, Gómez estaba vinculado con el conquistador y encomendero arequipeño Miguel Cornejo. ${ }^{6}$ Tenemos información de que Cornejo fue uno de los conquistadores que ingresó por la isla de la Puná; también estuvo en Cajamarca, luego en Cusco cuando fue cercado por Manco Inca, y después se trasladó a Arequipa llegando a ser tesorero, con indios a su cargo. Protegió a Diego Centeno, luchó contra Gonzalo Pizarro y en la guerra contra Francisco Hernández Girón, murió en la batalla de Villacurí. Su viuda, Leonor Méndez, se casó con Juan de Hinojosa, que era hermano del mencionado Gómez de Solís ${ }^{7}$ y además, desde 1559 encomendero de Machaguay en Condesuyo. ${ }^{8}$ Juana Núné, su suegra, mujer de Alonso Méndez, era consuegra del oidor Saravia, porque Alonso Picado, su nieto, se había casado con doña Mayor, la hija de Saravia.

doña Luisa de Vivar, se debe consultar en Presta (2000), uno de los estudios más importantes sobre la evolución de las encomiendas como forma económica, sus vinculaciones con otras actividades como la minería, el comercio, la agricultura y las empresas transformadoras de productos de la tierra.

6 AGI Patronato 105, R. 9. Méritos presentados por sus hijos. El mayor, Luis le sucedió en la encomienda de Quilca, Vítor, Socabaya, Porongoche y Quispillata; y Collaguas en la Chimba. Declara a su favor como uno de los conquistadores, Lucas Martínez, im. 56-61, 1561 -algunos de los documentos del AGI que usamos aquí están digitalizados en el Portal de Archivos Españoles (PARES) en cuyo caso, anotamos el número de la imagen (im.) donde se puede consultar; muchas veces suple bien la falta de foliación de los expedientes originales. AGI Justicia 471, ff. DCXXV-DCXXX, declaran todos los familiares por un asunto referido a un pago que Saravia hizo de un préstamo de 2 mil pesos que le hizo Cornejo.

7 AGI Justicia 475, f. 397.

8 AGI Justicia 432, $\mathrm{N}^{\circ} 2$ R. 6, la encomienda estuvo en poder del licenciado Miguel de Cuellar por nombramiento del virrey Antonio de Mendoza como marido en segundas nupcias de Ana Chacón, mujer que fue de Juan de Andagoya.
En este ya complejo tejido de parentescos encontramos a Diego Rodríguez de Solís, posiblemente el hermano de Gómez de Solís o un pariente cercano, el cual administraba los bienes familiares y quien tuvo a su cargo la hacienda de Miguel Cornejo, destinando incluso 20 mil pesos a la Corona para financiar la guerra contra Francisco Hernández. La riqueza de Cornejo fue resaltada por Lucas Martínez al dar testimonio sobre dicho conquistador (Lockhart, 1972, p. 116). ${ }^{9}$ Ahora bien, Luisa de Vivar (la esposa de Gómez de Solís) era otra hija de Juana Núñez, y por lo tanto, cuñada del encomendero Miguel Cornejo. Como testificara Lucas Martínez, estuvieron las tres (Leonor, Juana y Luisa) entre las mujeres que la gente de Gonzalo Pizarro se llevó de Arequipa para presionar a los encomenderos a que se sumaran o se mantuvieran aliados a su alzamiento.

Sobre el poder aquilatado por este grupo familiar hay algunos indicios, como por ejemplo una orden de cumplimiento de un auto de 1555. Al respecto, Francisco de Solís, vecino de la villa de Cáceres y padre de todos estos Solís, y Juan de Hinojosa pidieron que se hiciera prisionero a Gonzalo López, quien recibió en Tierra Firme de parte de Gómez de Solís, por mano de Miguel Cornejo, oro, barras de plata y 900 pesos para las costas a ser enviados a Espańa. Contrariamente, Gonzalo López los convirtió en sus propios intereses y negocios que hacía en Sevilla con Diego Diez Becerril y otros consortes.

Juan de Hinojosa era un encomendero que desde 1549 estaba en el Perú. ${ }^{10}$ Sirvió en Potosí deteniendo a Sebastián de Castilla y Egas de Guzmán; posteriormente, cuando Hernández Girón estaba cerca de Arequipa, la ciudad alzó bandera por los rebeldes huyendo este al puerto de Chule con otros servidores, donde encontraron un navío que los llevó a Chincha. Ahí llegó un emisario y gente del mariscal

9 De acuerdo con Lockhart (1972), posiblemente era plebeyo y su encomienda no era de las mejores. Estos testimonios muestran que sus redes relacionales en el naciente virreinato eran importantes y su riqueza mayor de la que pudiera mostrar el "valor" de su encomienda. Esos estimados sobre la capacidad de una merced de encomienda eran meramente indicativos, la realidad económica del encomendero era una cara diferente a la estimada por muchos.

10 AGI Justicia 432, 2, 6 f. 28v, im. 66. 
Alvarado, entregándoles el barco para ser trasladados a Lima. Luego, Hinojosa estuvo en Villacurí y ahí le robaron sus esclavos negros y caballos. También fue a Pucará donde desbarataron a Girón. Seguidamente, viajó a Chile acompañando a García de Mendoza, hijo del virrey. Por todos estos servicios recibió en premio su encomienda.

Como hemos constatado, Gómez de Solís era un vecino arequipeño con influyentes redes familiares. En 1550, ya vecino de La Plata, tuvo noticias de que entre Acarí y Arica existían algunas islas, por lo que solicitó una licencia para descubrirlas. ${ }^{11}$ En tanto, fue corregidor de Arequipa durante la guerra contra Hernández Girón y capitán del ejército real. Al respecto, existe un largo expediente sobre el manejo de recursos que utilizó Solís en esta guerra, donde no se salvó de importantes alcances a las cuentas que tuvo que justificar. ${ }^{12}$ En las diligencias de la visita de Muñatones se hizo averiguación el 6 de febrero de 1561 acerca de un navío de Gómez de Solís ${ }^{13}$ Puntualmente, se interrogó a Diego Rodríguez de Solís quien relató cómo Gómez -que era presentado como vecino de Charcas y residente en Arequipa-, se había trasladado a Lima hacía unos cuatro años para besar las manos del virrey recién llegado (fórmula muy recurrente que muestra el valor de la corte limeña). Al igual que Gómez, los demás encomenderos se dirigieron en tropel ante la autoridad colonial, con el objetivo de garantizar sus derechos o acceder a nuevos beneficios.

Tiempo después llegó al puerto un navío que había adquirido Gómez de Solís para el descubrimiento de las islas localizadas entre Acarí y el puerto de Arica. Como el virrey no autorizó dicha exploración, Solís ofreció entonces el barco a don García, hijo de aquel, que se aprestaba para salir a Chile. Con todo este entramado, Muñatones tenía mucho interés en que declarara Solís en Lima, para que abordara también el asunto de una mina en la jurisdicción de La Paz. Durante las indagatorias sobre Solís se fueron descubriendo varios intentos de soborno. En este confuso escenario, Solís declaró finalmente en

11 AGI Lima 92. En Levillier (1922, p. 12).

12 AGI Justicia 428, R $1 \mathrm{~N}^{\circ} 1$. Las cuentas de gastos en Arequipa en im. 115.

13 AGI Justicia 475, f. 397.
Arequipa y no profundizó en aquellos casos que requerían ser aclarados. Es probable que su avanzada enfermedad influyera en las pesquisas de los oidores, ya que justo en aquel año (1561) falleció en tierras arequipeñas (Presta, 2000, p. 186). Surge ahora la figura de Diego Rodríguez de Solís, un actor que entre bambalinas había participado en todos estos sucesos, asumiendo con potestad el negocio familiar.

El otro conminado era Alonso Galleguillos, quien fue comunicado del auto y apremiado a viajar el 10 de marzo de 1561, diligencias a las que Galleguillos no acudió. Sabemos que para el 10 de abril aún se encontraba en Arequipa, siendo requerido por el comisionado Luis Flores que lo hizo testificar ante el corregidor Alonso Manuel de Anaya. En este contexto, la figura de Galleguillos hay que examinarla como a un "personaje secundario", que cumple un papel en la trama e incide ciertamente en el ritmo del relato. Veamos entonces algunos acápites de su vida y contactos sociales.

Alonso Galleguillos era un hombre de 40 años, mayordomo de la encomienda de Noguerol de Ulloa en Collaguas y pese a desenvolverse en los ambientes judiciales y letrados, no sabía leer ni firmar (Cook y Cook, 1991, p. 40). Cuando se presentó ante el corregidor, expuso de muchas cosas menos de los temas requeridos. En su largo testimonio explica que tenía una compañía con el mercader Juan Vázquez, quien al parecer negociaba también en Chile. Asimismo anduvo junto con Noguerol de Ulloa realizando probanzas de méritos en Lima para llevarlas a España. Pese a ser iletrado, Alonso Galleguillos era un comerciante conocedor de los manejos de las rentas, aspirando a detentar una encomienda. Negociaba por entonces ante la autoridad para que le asignaran los indios de Characato de Pedro Godínez, vecino de Arequipa que pretendía volver a España. Según Galleguillos, para que aquello se concretara solicitó al marqués de Cañete, por intermedio del secretario de gobierno Pedro de Avendańo, que le traspasaran dichos indios ya que ambos españoles provenían de la misma tierra. Pese a las intenciones de Alonso Galleguillos, debemos recordar que Godínez había sido fundador de Arequipa (Málaga, 2013, p. 206) $y$, aunque su encomienda era pequeña, tenía muchos contactos e influencias. Efectivamente, anhelaba regresar a la península ibérica, por lo cual quería 
vender su encomienda, pese a estar fuera de toda razón jurídica. Aparte del citado Galleguillos, hubo otros interesados, como era el caso del encomendero de Chiguata Francisco Bosso, que estaba dispuesto a pagar 6 mil pesos ensayados, mientras aducían como razón la unificación del grupo indígena de la encomienda; pero, al fracasar la gestión de Bosso, Diego Gutiérrez, que había sido administrador de Hernando Pizarro, logró hacerse de la encomienda con ayuda de Lucas Martínez (Galdós, 1987, pp. 302-306)..$^{14}$

Igualmente, existían otros personajes que formaban parte de este entramado. Por ejemplo, el citado Alonso Galleguillos declaró que Diego García de Villalón, mayordomo de Ana de Velasco, la viuda del mariscal Alvarado, había dado a Pedro de Avendaño a través de su ayudante Antonio de Quevedo - muy activo en todos los tratos del escribano de cámarauna taza de oro que pesaría hasta 200 pesos. Diego García de Villalón, que muy tempranamente fue socio de Lucas Martínez y ayudante en la conquista de Chile, era mayordomo de la encomienda de Songo que había pertenecido a Alvarado. Diego García, a diferencia de Galleguillos, llegó a fuerza de gestiones políticas y gastos de dinero que obtuvo de sus negocios, a ser encomendero en La Paz. En tanto, Alonso Galleguillos sabía aquello de la dádiva a Avendaño, lo cual demostraba la estrecha relación que existía entre el primero y Quevedo. ${ }^{15}$ Antonio de Quevedo

14 AGI Indiferente 1252, Tasas de Arequipa, junto con otros preciosos datos de los repartimientos de Arequipa y su multietnicidad, viene el dato de los indios de Characato que efectivamente, por merced de los comisarios, fue encomendado en Diego Gutiérrez por dos vidas, por dejación de Pedro Godínez "que se los vendió". Le sucedió su hijo Juan Gutiérrez hasta su muerte. Vaco lo dio Toledo a Francisco Ruiz de Navamuel. La renta era poca: 607 pesos ensayados, $200 \mathrm{f}$ de trigo a peso y medio, 200 de maíz a peso, 380 aves a tomín y 12 fanegadas de sementera.

15 AGI Justicia 475, residencia de Quevedo. El legajo tiene tres cuerpos, el principal de ellos, el segundo, es un grueso expediente correspondiente a la visita de Briviesca de Muńatones cuya carátula reza: "Quaderno [roto] de la visita de residencia que se tomó en este reino del Perú a los oidores y demás oficiales de la Real Audiencia de la ciudad de Los Reyes. Van todos los cargos y descargos de los oficiales de la dicha RA y el proceso y capítulos que don García de Mendoza dio contra los dichos oidores. Va en setecientas y veinte y cuatro hojas fue uno de los oficiales a los que se residenció en la visita. Como acabamos de señalar, era amigo de Galleguillos, el cual llevaba su hacienda y enviaba por navíos algunos obsequios. ${ }^{16}$ Alonso Galleguillos había prestado a Pedro de Avendaño alrededor de mil pesos que dijo solventaría con dinero proveniente desde Potosí. Insinuó igualmente a Quevedo que manifestara que dicho monto se lo quedase a cambio de ayuda para lograr la cesión de indios que quería de Godínez, lo que a la postre no consiguió.

Para el 30 de abril de 1561, Alonso Galleguillos se apersonó en Lima limitándose solo a decir que entregó su testimonio ante Luis Flores. ${ }^{17}$ No sabemos por qué el acucioso Muñatones no se percató de que Galleguillos no había declarado acerca de lo que motivó su presencia en Lima. Tal vez, suponemos, puede ser por el testimonio de Avendaño, quien era el máximo implicado en los malos manejos de la visita. De hecho, el informe apunta a que el propio Alonso Galleguillos comentó que al abordar el pleito en la Audiencia contra Noguerol de Ulloa (el cual se encontraba en España ventilando un sonado caso de bigamia trasatlántica), por haber abandonado la milicia en tiempo de la alteración de Francisco Hernández Girón, él tuvo poder para representarlo, aunque no era admitido como parte hasta que envió al oidor Cuenca dos fuentes y dos candeleros de plata labrada que le costaron 200 pesos (Cook y Cook, 1991). Sabemos que los llevó un indio "de" Galleguillos llamado Francisco. ${ }^{18}$ Pese a todo, y en esta confusa situación, Alonso Galleguillos no llegó a ser encomendero, pero extrañamente "tenía indios". Y dicho sea de paso, mantuvo buenos conciertos con Ińigo de Bocanegra, el mayordomo de la encomienda de Tarapacá cuando estuvo en poder de Jerónimo de Villegas, manejando ambos los diezmos de toda la provincia como resultado de un remate que efectuaron (Villalobos, 1985). Incluso, tuvo además

numeradas y escritas en todo y en parte y va cerrado y sellado". Firma Domingo de Gamarra el secretario de la visita.

16 AGI Justicia 475, f. 41v. Debemos tener presente, como veremos más adelante, que este fue con Avendaño uno de los declarantes estrella de la causa de Santillán contra el relator Rodríguez de Cartagena por haber apoyado a Lucas Martínez, AGI Justicia 1060.

17 AGI Justicia 469, f. CCCVI.

18 AGI Justicia 469, f. CXXXIX. 
una compañía con Villegas antes que este muriera, ${ }^{19}$ llegando con el tiempo a administrar la encomienda de Tarapacá. ${ }^{20}$

\section{La escena: buscando al encomendero}

Lucas Martínez Vegaso fue conminado el 12 de marzo de 1561 por el corregidor Alonso Manuel de Anaya para que se presentara en Arequipa bajo graves penas. El auto del corregidor expresa que, si no es habido, se comunique "a sus criados, yanaconas o esclavos que residen en el mineral de La Cruz" (Huantajaya) $^{21}$ para que informen con prontitud su paradero (Gavira, 2005; Donoso, 2008; Mukerjee, 2008; Hidalgo, 2009). Sabiendo que en dicho mineral moraba Martínez Vegaso, llegó a fines de marzo el comisionado Domingo de Agurto con el propósito de notificar el mandamiento de Muńatones, sin poder localizar al encomendero. Empero, al enterarse de que había arribado el comisionado a Ique Ique, Lucas Martínez se fue de inmediato al oasis de Pica, diciendo que si llegaba Agurto enviara con un indígena una carta con sus requerimientos. Así, el comisionado, al llegar, registró diversos testimonios en torno al encomendero y sus actividades vinculadas a la minería de la plata. Paciente, no sin interés pues este escribano cobraba por día de trabajo, remitió una nota al citado Lucas y utilizando un indio de chasqui envió a Pica la solicitud requerida. Aunque pasaron cuatro días, el comisionado no recibió noticia alguna.

En tanto, apareció en el asiento de Huantajaya el padre Alonso Maldonado, clérigo de la encomienda, quien informó que recibió durante esos días una

19 AGI Justicia 401, Almoneda de los bienes de Villegas.

20 AGI Lima 121, Expediente de Hernando de Santillán.

21 AGI, Justicia 471. Es llamativo que las referencias documentales señalen al asiento como La Cruz, quizás fue una expresión para identificar una veta de plata o la denominación hispana para las minas conocidas localmente como Huantajaya, pero ciertamente nos referimos al mismo asiento que tratamos en este artículo. El mineral de plata de San Agustín de Huantajaya, fue trabajado en tiempos del Inka y aproximadamente a partir de la década de 1540, Lucas Martínez comenzó los trabajos con la incorporación de yanaconas, negros y mestizos para extraer "papas" de plata. carta de Lucas Martínez en la que señalaba que iba camino de Atacama, al sur de Pica. Como es de suponer, Domingo de Agurto, al enterarse de los comentarios del cura Maldonado, contó con pruebas de que Martínez no quería ser notificado del auto. Entonces, optó el comisionado por dejar el mandamiento al sacerdote y a los esclavos del encomendero Antón Martín Bran, Antón Herrero Berbesí, Francisco Biafra, Pedro Bran, Antón Banol y Jerónimo Angola mediante un testimonio firmado al cura y "al dicho Antón Martín negro por ser más ladino que los otros y parecer de más razón y recado". ${ }^{22}$ Es interesante notar la presencia de Antón Martín o Martínez, el "esclavo más ladino", a quien Lucas llama en su testamento "mi negro", el cual tenía a su cargo las llaves de algunos bienes y al que dio la libertad luego de su muerte (Trelles, 1983, p. 131), lo que demuestra que algunos esclavos eran fundamentales para las actividades de estos encomenderos (Díaz, Ruz y Galdames, 2013). De igual forma, el escribano Agurto puso por testigos a todos los esclavos negros y a un mestizo llamado Sebastián Velásquez de Talavera, otro de los servidores del empresario minero, y a Cornieles Roberto. Pasados los días, el 5 de abril Agurto ya se encontraba en Arica rumbo a Arequipa.

Juan de Contreras era un personaje que figuró en el testamento de Iñigo de Bocanegra, el mayordomo de la encomienda cuando estuvo en poder del rival de Martínez, el citado Jerónimo de Villegas. Tenemos información de que Contreras había realizado negocios con Bocanegra, pagando por él en Arequipa a un comerciante que le había vendido "carneros”, probablemente en Arica o Tarapacá, y manejaba algunos negocios cuando todavía Bocanegra tenía lazos con la administración de la encomienda de la heredera de Villegas, antes que volviera a Lucas Martínez (Villalobos, 1985, p. 415). El otro, Corniel o Cornieles Roberto, era un criado en la acepción de allegado, un "extranjero" por su nombre. Tenía cerca de 26 años y Lucas lo trataba en sus cartas como "hijo". Justamente, al momento de la visita se encontraba en el mineral de Huantajaya, regresando inmediatamente a Arica donde al parecer residía.

22 AGI, Justicia 471. 
Ahora bien, la información de la ausencia de Lucas Martínez Vegaso posee ciertas particularidades que es necesario comentar. Como ya hemos expuesto, Domingo de Agurto al arribar a Iquique y no poder notificar del mandamiento de Muñatones elaboró un informe junto con testigos del lugar. Así, compareció Martín, indio yanacona de Lucas, natural de Atico, ladino en la lengua de Castilla, por lo que fue requerido como intérprete para otros testimonios. Martín juró conforme a derecho por la ley cristiana. Luego, compareció un indio llamado Chuysa, natural de Iquique; dijo "no ser cristiano" por lo que no se le tomó juramento (Díaz, Martínez y Ponce, 2014). ${ }^{23}$ Chuysa expuso que el miércoles por la tarde estuvo en las minas adonde fue con agua desde Iquique y vio al encomendero, quien manifestó que le dijese al yanacona Martín que en cuanto llegase el barco, avisara de inmediato. El yanacona confirma aquello y agrega que esa mañana, al ver el barco, mandó a un indio llamado Antón Çilauca para dar aviso. Agurto entonces se enteró de la fuga de Lucas Martínez tan pronto llegó al puerto. Otro declarante fue Puyle, indio que apuntó ser también natural de Iquique, y no juró "por no ser cristiano". Este confirma que el día anterior vio a Lucas en las minas, pero no sabe cuándo se había marchado. El tercer testimonio lo tomó Agurto con la interpretación del mestizo Sebastián Talavera.

De esta manera, habiendo recabado dichos testimonios, el comisionado marchó al día siguiente a las minas de Huantajaya. Allí, con la ayuda de Talavera, interrogó a un yanacona de nombre Pedro, el cual era natural del Cusco y servía como despensero del mineral. Tras jurar Pedro, dijo que el jueves cuando vino "el indio de la mar" con la noticia del barco, Lucas se marchó de inmediato a Pica señalando que dijesen que hacía cuatro días había partido. Como advertimos, ya nos enteramos de que el encomendero tenía un servicio rápido de información, instruyendo, a su vez, que mintieran tras su fuga.

23 La escasa presencia de sacerdotes en el litoral de Tarapacá como en la sierra de Arica es una situación que se mantuvo durante toda la época colonial, por lo que encontrarse con indios no cristianizados o sin recibir los sacramentos ante la ausencia de los misioneros, fue un problema permanente tanto para las autoridades eclesiásticas como para los caciques (Díaz, Martínez y Ponce, 2014).
Iquique y el asiento minero de Huantajaya eran una unidad económica y social donde habitaban mestizos, negros y yanaconas, tanto del Cusco como de la costa de Arequipa, que eran cristianos y ladinos en la lengua castellana, como también indios "de la mar" que hablaban otras lenguas. ${ }^{24}$ Aquel fin de semana, Agurto no hizo ninguna diligencia pero anotó, el domingo 30 "a la tarde a puesta de sol”, detrás del auto del corregidor que Lucas marche urgente a Lima, dejando un testimonio firmado con el padre Maldonado. Para el lunes 31 declaró Antón Martín, negro bran, quien confirmó el testimonio de los indígenas. Lo mismo expuso Antón, negro berbesí, herrero de Lucas. ${ }^{25}$ Queda bastante claro que nadie ocultó el ardid de Martínez ante el comisionado. Sin cambiar la fecha, Agurto dejó sentado que asimismo dio al negro Antón copia para que le comunicaran a Lucas y ańadió como testigo a Corniel Roberto.

Días antes, el mismo Corniel había recibido una carta de Lucas Martínez, cuando estaba en las minas de La Cruz. El escrito dice lo siguiente:

Hijo Corniel Roberto/ supe que había llegado a Tarapacá un hombre que se dice Fabián Bernal que vino de Copiapo por mandado de Francisco de Aguirre a saber nuevas y hace vuelto camino de Copiapo de que estoy corrido voy tras él para preguntarle las nuevas que quería saber y pudiera ser que si no le alcanzo antes me llegue a Atacama/ hacedme placer que hagáis un viaje de agua y me traigáis cinco o seis haces de totora que en Pisagua mandé que tuviesen junta los indios para acabar de cubrir el aposento para mí y mandadles que hagan otras tres este-

24 Los “indios de la mar" que hablaban otras lenguas, tradicionalmente han sido asociados de acuerdo a las referencias cronísticas como "changos". Sin embargo, no existe certeza documental que permita entregar información confiable sobre su etnicidad, que tal vez estuvo vinculada a prácticas pesqueras y denominaciones como "camanchacos". Estas materias ciertamente merecen una discusión etnohistórica profusa.

25 Los africanos que llegaron como esclavos al actual norte chileno, provenían desde Guinea, Congo y Angola; pero también, tal como se evidencia, vendrían de la nación "Bran” (Ghana) y de la nación "Berbesî" (Senegal) (Díaz, Ruz y Galdames, 2013). 
ras que son menester y si el padre Hernando Diez Rojo viene con vos decidle que me haga merced de estarse en este asiento hasta que yo vuelva doctrinando esta gente y la de Hique hique y si no viene con vos el padre Rojo enviad el barco en haciendo un viaje de agua con el yanacona y los indios a Arica que ellos le volverán a traer un viaje con lo que fuere menester y quedaos en estas minas hasta que yo vuelva que estará todo perdido si no hay quien mire por ello/ El padre Alonso Maldonado se acertó a hallar aquí y le rogué se estuviese hasta el domingo de ramos y confesase esta gente y la de Hique hique/ Al padre Rojo beso las manos y no le escribo por la prisa que tengo que tenga por suya esta carta y si el no viniese el padre Maldonado os la leerá Jhs con todos, lunes veinte y cuatro de marzo 1561

\section{A lo que os cumpliere \\ Lucas Martínez a mi hijo Cornel Roberto. ${ }^{26}$}

La carta revela en parte el motivo por el que Lucas no se dejó ver por Agurto. Un emisario del conquistador Francisco de Aguirre había llegado a Atacama para "saber nuevas". Aguirre estaba en Copiapó, donde pasó algunos meses luego de haber regresado a Chile al enterarse de la muerte de Valdivia y haber enfrentado a Villagra y al hijo del virrey, García de Mendoza, dando cuenta de la tensión política que se vivía en Chile. ${ }^{27}$ Lucas Martínez no era ajeno a esos avatares, debido a que parte de sus negocios estaban conectados con esas regiones. Como vemos, es posible que el encomendero estuviera determinado a partir justo cuando llegó el comisionado.

La carta enuncia que junto a Cornieles se encontraba el padre Hernando Diez Rojo. Se trata de un clérigo del que tenemos noticias actuando en este territorio. Observamos que el servicio sacerdotal no

26 AGI, Justicia 471.

27 Consignemos que en 1553 muere Pedro de Valdivia y Aguirre regresa a enfrentarse con Villagra. En 1557 García de Mendoza es gobernador en Chile. Para 1559 Aguirre pasa unos meses en Copiapó dedicado a su finca Castillo de Montalván. era suficiente solo con el padre Maldonado; prueba de ello es que los indígenas que testificaron aún no eran católicos. Los antecedentes nos permiten subrayar que por lo menos en 1561 hay dos religiosos al sur de la encomienda, los clérigos Rojo y Maldonado. Pareciera este último haber sido el doctrinero de Tarapacá, mientras que el primero recorría el litoral entre Arica e Iquique.

$\mathrm{Al}$ respecto, existe documentación interesante sobre el padre Rojo que lo confirma como doctrinero de Arica y la encomienda tarapaqueña. ${ }^{28}$ En tal sentido, en Lima el 15 de septiembre de 1561 el conde de Nieva hizo declarar a García de Mendoza, pues había recibido información de que el padre Rojo llevaba a Lima ciertas cartas que le había dado Francisco de Aguirre. El capitán Aguirre pretendía ser el sucesor de Valdivia, pero se encontró con un litigio con Villagra, siendo retirado por el marqués Hurtado de Mendoza para poner en ese cargo a su hijo. Francisco acusaba a García de Mendoza de haberlo despojado de sus bienes, despilfarrado la hacienda real y dispuesto para sus criados los recursos de repartimientos. ${ }^{29}$ Desde Copiapó, donde tenía su residencia y repartimiento, Aguirre mandaba para la Audiencia diversas misivas tocantes al servicio del rey, y entre ellas, ciertas del marqués a su hijo cuando era gobernador de Chile. En tanto, el destituido gobernador, cuando regresó a Lima, al pasar por Arica había tomado los despachos por la fuerza al dicho clérigo, abriéndolos y quedándose con ellos. $\mathrm{Al}$ respecto, preguntado García sobre las cartas que venían para los oidores y para Muñatones, dijo que por febrero o marzo pasados, sabiendo que Francisco de Aguirre había "tomado por fuerza y haciendo malos tratamientos a Felipe de Mendoza", su hermano natural, y a Francisco de Ulloa -el explorador- las cartas que su padre le mandaba, quiso castigarlo, pero para no causar más escándalo y sabiendo que habían llegado el virrey y el visitador, decidió

28 AGI Justicia 1064 "Declaración de don García de Mendoza hijo del Marqués de Cañete sobre ciertas cartas que le escribió su padre". En Madrid a 27 de julio de 1563 entregó este testimonio juntamente con la residencia que fue tomada a los oidores y oficiales reales de la Audiencia de Los Reyes el licenciado Cristóbal Ramírez.

29 AGI Lima 119, carta de Aguirre preso en Lima en 25 de enero de 1558. 
dejar sus tenientes y procuradores para su residencia y partir a Lima a informar que

[...] viniendo descuidado por el puerto de Arica topó en él al padre Roxo y sabido por este que depone que traía despachos del dicho Francisco de Aguirre a esta corte y a personas particulares y que entre ellos traía los que había tomado al dicho don Felipe su hermano, le envió a decir al dicho Roxo clérigo con un Solís y Diego de Santillán que le diese los despachos que traía sino que le traería preso en el barco por la información que contra él había de somético, y el dicho clérigo de miedo los dio a este que depone. ${ }^{30}$

García afirmó que solo abrió sus cartas y las otras las entregó de vuelta al clérigo, acción que hizo públicamente.

En la apertura de las cartas del marqués, se refiere a sí mismo como padre Hernando Díaz Rojo, tal como lo llama Lucas. Veamos ahora la notificación de Domingo de Agurto:

A la ora desta llegué en este puerto donde por carta de VM que escribe a Cornieles he sabido va VM a Pica y porque yo vengo por mandado del señor comendador licenciado Briviesca de Muñatones a tomar a VM su dicho en cierto caso en que es seńalado por testigo suplico a VM me haga merced de se llegar a estas sus minas donde estaré esperando a VM hasta que venga porque aunque sea estar aquí un mes o más no iré sin que VM declare su dicho porque es sobre la residencia de los oidores y es muy necesario el dicho de VM para declaración de la verdad. También traigo un mandamiento del corregidor de Arequipa sobre los indios que andan en las minas y en el barco pero en este harase lo

30 AGI Justicia 475: Diego Rodríguez de Solís está el 6 de febrero declarando sobre el navío de Gómez. Ese año de 1561 se hizo el juicio de residencia a don García que en 1560 habíase aprestado a regresar al Perú porque ya estaba en camino el Conde de Nieva y en enero de ese 1561 se enteró de la muerte de su padre; el 3 de febrero de 1561 salió para Lima de un puerto llamado Papudo. que VM mandare pues he entendido que el andar en las minas y barco les es provechoso a los indios. No se ofrece otra cosa. Nuestro señor guarde la muy magnífica persona de VM como sus servidores desean de Yque Yque jueves XXVII de marzo IUDLXI

\section{Domingo de Agurto. ${ }^{31}$}

Conjuntamente con el requerimiento para que testificara el encomendero, nos enteramos de que la gestión buscaba igualmente relevar una serie de antecedentes sobre los malos tratos que recibían los indios de Lucas Martínez. Tiempo después, el 2 de abril, desde el mineral de La Cruz este escribió al corregidor Anaya exponiendo que luego de recibir la carta de Agurto volvió a buscarlo y no lo pudo hallar. Suplica Martínez que trabaje "por que no vaya hombre del todo desnudo" (Lockhart, 1972, p. 100; Martínez, 1936, p. 11). También requiere que detenga el navío hasta que él llegue al puerto.

Hemos constatado que Alonso Manuel de Anaya no ocultó la correspondencia que llegó a manos de Muñatones, aunque suponemos que no había correlación entre el trato que se traían Martínez y Anaya con la comisión que tenía Agurto. Puntualizando, el corregidor estaba ya informado de los pasos que quería dar el encomendero e incluso este solicitó que recabara los recursos de los vecinos encomenderos para llevar adelante la gestión en Lima y defender por ellos la perpetuidad de la encomienda. En otros términos, existía dicha complicidad, por lo cual Lucas Martínez debía pasar por el puerto de Arequipa sin que nadie se enterara (salvo su familia y su aliado, el ya citado Diego Gutiérrez). Acto seguido, al regreso de Agurto, cuando Anaya ya estuviera informado, viene la provisión del mismo corregidor para que el comisionado vaya a buscar a Lucas, fechada en Arequipa a 22 de abril de 1561. Aquí se asume que el encomendero no quiso comparecer y resume la historia que describe en los documentos anteriores.

Detengámonos en la figura de Alonso Manuel de Anaya. Para la medianía del siglo XVI, los corregidores eran funcionarios con una envestidura de alto nivel, y no solo por la relevancia ceremonial de sus

31 AGI, Justicia 471. 
funciones, sino que también eran los representantes absolutos del Rey en un territorio administrado por un asiento de vecinos. Debían encabezar el cabildo y salir en defensa militar de cualquier intento de sedición, que para entonces era una situación recurrente. Algunos de los proveídos en esos cargos fueron también encomenderos y vecinos notables, pero lo más común es que no lo fueran. Entre estos estuvo Anaya.

Estos corregidores no eran necesariamente conquistadores ni vecinos, pero tenían un importante rol en la administración de justicia y la aplicación de las políticas imperiales. Anaya era un personaje que tenía suficiente prosapia y poder para estar en primera línea en la definición de la política virreinal. Su rastro lo podemos ubicar primero como corregidor en Trujillo. ${ }^{32}$ Es posible que arribara para asumir el cargo del corregimiento o un poco antes, como otros corregidores que concuerdan con su perfil, como Antonio de Oznayo, Gil Ramírez Dávalos o Pedro Pacheco. Anaya fue nombrado visitador por el marqués de Cañete (Jiménez, 1965, p. 217), y en el cargo visitó Maranga, Huatica y Lima y fue pionero de las famosas reducciones (Coello, 2002). Luego, ocupó el cargo en el cual ahora lo vemos actuando en Arequipa. Fue también nuevamente corregidor y justicia mayor de Quito, Cuenca, Guayaquil y Puerto Viejo por nombramiento de 6 de marzo de 1564 , que constituye una jurisdicción propia de lo que sería una Audiencia. Posteriormente, sería el mismo personaje quien, siendo corregidor de Lima, participó y propició la reducción del Cercado en 1567 (Coello, 2002, p. 198).

Anaya al poco de su mandato en Arequipa, a inicios de 1562, adquirió protagonismo entre los allegados al partido de los indios que capitaneaba fray Domingo de Santo Tomás. Los curacas y señores de Lima en enero de 1562 lo pusieron entre quienes tenían su poder para representarlos contra la perpetuidad $^{33}$ y los de Arequipa, entre los cuales estaban los indios de Lucas Martínez encabezados por Pedro Cusi Inga (Trelles, 1983, p. 119). En marzo de ese mismo año, como una muestra de la estrecha relación entre ambos, fray Domingo lo tenía al tanto de

32 AGI Justicia 471, preguntas del interrogatorio lo implican en un incumplimiento de detener a un acusado de sedicioso por indicación del oidor Mercado.

33 AGI Indiferente 1624. las negociaciones y las juntas de los curacas (Lisson, 1944, p. 202). ${ }^{34}$ El trato que también daba a Martínez guardaba relación con su cargo, y al ser nombrado para representarlo en las negociaciones acerca de la perpetuidad, explica en parte que el encomendero pidiera que gestionara fondos para su misión. Pero a su vez, Anaya no estaba ajeno a las demandas de los indígenas y era consciente de los abusos que se cometían a través de los servicios personales que ya habían sido proscritos, siendo él uno de los que opinó para que estos fueran definitivamente erradicados. ${ }^{35}$ Por tales motivos, pensamos que Anaya dio un fulminante auto para que Agurto volviera a las tierras de Lucas, incluso estando informado de las intenciones del encomendero, arguyendo intereses propios y no solo por la convocatoria de Muńatones.

En paralelo, el comisionado Domingo de Agurto recurrió a otra instancia fundamental de esa naciente sociedad colonial, la Iglesia. Pedro de Cáceres entonces era juez y visitador general del Obispado del Cusco encabezado por el obispo Juan de Solano. A él recurrieron para que ordenara al cura de Tarapacá Alonso Maldonado declarar sobre los procedimientos del encomendero. El auto requería que Maldonado respondiera por algunos capítulos del pliego, como por ejemplo por qué Lucas Martínez se ausentó de las minas al saber que iba Agurto; sobre la carta que dio a Cornieles y otros antecedentes del indio que llevó carta y no volvió; verificar si entre Pica y Huantajaya efectivamente habían doce leguas de distancia, y si un indígena sin carga las recorre en tres días, ya que se interpretaba que el mensajero había sido retenido por el encomendero. En otro capítulo, el cura debía declarar si los indios sufrían perjuicio y daños en sus labores en las minas; si recibían paga por el servicio personal en las minas de plata y barcos, y pesquisar sobre episodios de violencia a los yanaconas. A su vez, Maldonado debía clarificar cuántos eran efectivamente los indios yanaconas, negros y mulatos que servían en las haciendas en Tarapacá y alrededores. Se solicitaba, además, averiguar si los hermanos Lucas y Alonso García daban malos tratos a los naturales como "tomarles sus chácaras y haciendas como otras cosas". ${ }^{36}$

34 Lisson refiere a AGI Lima 313.

35 AGI Indiferente 1216.

36 AGI Indiferente 1216. 
La pesquisa es peculiar, no se explica sin alguna protesta de los indios agitados por el debate en torno a los dispositivos que intentaban perpetuar a los encomenderos. En este período, poco tiempo había transcurrido de los últimos grandes alzamientos de los encomenderos, atizados por el intento de suprimir los servicios personales y escaldados de las retasas que los oidores concedían a los indígenas cuando estos presentaban sus protestas por los abusos en el cobro de tributos, las conmutaciones de especies y el servicio personal. En el caso del desierto tarapaqueño, las protestas giraban puntualmente en torno al servicio en los barcos y en las minas.

Volvamos a Domingo de Agurto. Estando en Arica el viernes 2 de mayo de 1561, escribe el informe al enterarse de que Lucas Martínez ya se había embarcado para Lima. En tanto, se limitó a tomar declaración a Juan de Contreras quien, ya sabemos, era mayordomo del encomendero. Este declaró que hacía diez días que Lucas "fue al puerto por mar en un barco suyo desde las minas de La Cruz para desde allí ir a la ciudad de Los Reyes”. Luego, Cornieles Roberto junto a un criado llamado Enrique y cuatro esclavos negros confirmaron lo expuesto por Contreras. Por otra parte, desconocemos el tenor de las respuestas del padre Maldonado y no hay constancia de que se hubiera hecho nada respecto al manejo de los tributos y servicios.

\section{En el laberinto de la justicia}

Lucas Martínez llegó a la ciudad de Lima en mayo de 1561. Ya no volvería a su encomienda en Tarapacá ni tampoco a Arequipa. En la capital, se dedicó denodadamente a defender la posesión de su encomienda frente a sus adversarios. Como ya hemos descrito, su caso había sido crucial en el descubrimiento del mal comportamiento de los oidores, oficiales reales y hombres de leyes adscritos a la corte de la Audiencia.

Todavía queda información que hemos podido hallar para puntualizar la completa biografía de Lucas Martínez que se tiene gracias a los aportes de los trabajos de Trelles (1988), Villalobos (1979) e Hidalgo (2004). Pero no será este el momento de hacerlo. Solo valga recordar que luego de su implicación en el alzamiento de Gonzalo Pizarro y por maniobras de quien fuera su amigo Jerónimo de Villegas, Lucas fue acusado, enjuiciado y condenado por traidor. Perdió su encomienda y esta fue a parar a manos de Villegas. Desde entonces Jerónimo de Villegas, que había dado muestras de habilidad empresarial con la encomienda de Piura que asumió por matrimonio, tuvo la oportunidad de desarrollarla en los antiguos dominios de Martínez. ${ }^{37}$ Lo hizo bastante bien, aunque el esplendor de las minas de Huantajaya que permitió el auge económico de Lucas Martínez ya había declinado. Mientras tanto, Lucas no solo salvó la vida, sino que logró mantenerse en la corte limeña a pesar de la orden de destierro que pendía sobre él. Por años litigó su desagravio y la recuperación de su honra, a la vez que solicitó la restitución de sus bienes y encomienda. Su capacidad económica y sus vínculos con las redes del poder colonial permitieron sufragar el asunto.

Como contrapunto, luego del alzamiento de Hernández Girón, Jerónimo Villegas cometió un error de cálculo político y terminó como su competidor, acusado de traición. Eso, gracias a la estrategia de Lucas Martínez que apoyó a los oidores que sofocaron, no sin escándalo político, aquella última gran asonada encomendera, permitiendo que se inclinara la balanza a favor del despojado encomendero. Al tiempo, Martínez logró un fallo favorable de restitución por parte de la Audiencia, instancia a la cual apeló Villegas, y aunque quiso llegar a un acuerdo, murió en este lapso (Lockhart, 1982, pp. 300-305).

37 AGI Lima 121, relación de servicios de Hernando de Santillán pidiendo indios. Villegas y María Calderón se casaron en Piura (ca. 1545) donde se firmó la dote. Villegas tenía una verdadera fortuna en la época de la boda, afincada en Piura donde tenía dineros, ganados, esclavos, chácaras y heredades y otras granjerías e indios como vecino de Piura, avaluados según el interrogatorio en 100 mil pesos. El interés de la averiguación es mostrar que el pleito entre Lucas y Villegas se trabó después de la muerte de la madre y que antes su dote y las granjerías de Villegas se multiplicaron en por lo menos 80 mil pesos de buen oro sin intervenir en ello el negocio de la encomienda del sur. Dice que al casarse Calderón "estaba muy rica" y valían sus bienes más de 20 mil pesos. El repartimiento de Garruchamba que poseía fue administrado por Villegas por tres años y cobraría cada año más de 8 mil pesos "porque a la sazón ninguna tasa había”, según parece los indios sacaban oro de mina. 
El deceso de Villegas permitió que se reacomodara el bando rival que pretendía la encomienda. En tanto, en este difuso tejido de vínculos sociopolíticos y familiares que detentaban el poder colonial aparece la figura de Hernando Santillán, sobrino del oidor del mismo nombre. Hernando, tempranamente había logrado un acuerdo con el tutor de la hija de 10 años de Jerónimo Villegas, para casarse con ella (Levillier, 1922, p. 253 y ss.). ${ }^{38}$ Llegaron así a tomar posesión de la encomienda antes de que Lucas Martínez obtuviera carta ejecutoria para recuperar sus dominios. Con ayuda del tío, maniobraron como parte contraria en la causa por la posesión de la encomienda. Consignemos que justo en ese estado de cosas se produjo la visita de la Audiencia.

El largo proceso por la pérdida y recuperación de la encomienda de Lucas Martínez está reunido completo en un extenso expediente. ${ }^{39}$ En él están contenidos los pormenores y la sustanciación de la síntesis de este aparatoso relato. Algunos hitos es necesario que los anotemos. En su testamento, Villegas dejó por tutor de Ana a Juan de la Torre. Luego, recién en 1557, Lucas Martínez obtuvo ejecutoria a su favor en el pleito. ${ }^{40} \mathrm{Al}$ año siguiente se realizó la almoneda de los bienes de Villegas. ${ }^{41}$ Los que obtuvieron el remate de dichos bienes, incluyendo a esclavos y ganados (ovejas de Castilla, vacas, cabras, algún carnero de la tierra, etc.), con un monto de 12.265 pesos y cuatro tomines de plata ensayada, fueron Martín de Valencia y Diego Gutiérrez, quienes los traspasaron a un amigo en común: Lucas Martínez. Aquel año volvió por fin el viejo encomendero a sus dominios. Aunque la parte de Santillán y la hija de Villegas no dejaron el sitio fácilmente. Todavía se esforzaron varios años después en presentar testigos que afirmaban que vieron en ese tiempo a los mayordomos de Villegas trajinar con el tributo y administrar la zona. En este contexto, el terreno del juego se trasladó a la

38 Levillier (1922) refiere AGI Lima 92.

39 AGI Justicia 401. 1556-1560 Lucas Martínez Vegaso, vecino de la ciudad de Arequipa, contra los herederos del capitán Jerónimo de Villegas, difunto, vecino de la misma ciudad, sobre el derecho a las encomiendas de Taracapá y Arica. 7 piezas.

40 AGI Justicia 443, N 1 , R. 2. Pleito por la posesión de los indios de Tarapacá entre los sucesores de Lucas Martínez y el fiscal.

41 AGI Justicia 401, im. 102/1703.
Audiencia, como lo hizo Lucas, apremiado porque sus asuntos privados eran nuevamente un asunto de público interés por la visita de Muñatones.

Uno de los primeros testimonios de la visita de la Audiencia fue el de Cristóbal Ramírez de Cartagena. Este era un letrado de 36 ańos con una vasta experiencia y que hacía poco había llegado como relator de la Audiencia. Había tenido un papel determinante en el fallo final favorable a Martínez. ${ }^{42}$ Cartagena cuenta que la sentencia del caso se descubrió antes de la audiencia pública, lo que estaba vedado. Así, se presentaron antes de la audiencia pública unas "peticiones en su deshonor" pretendiendo amedrentarlo. Muñatones inquirió si Santillán había hablado o intentado persuadir en este negocio, a lo que Cartagena respondió que personalmente no, "aunque algunas veces le envió a decir que se viesen”. ${ }^{43}$

Cristóbal Ramírez de Cartagena fue tercero en dos artículos de la causa. Uno, el referido a la recusación interpuesta por Santillán al doctor Saravia, con el que tenía una larga desavenencia: "en este artículo le habló el mismo Hernando de Santillán haciéndole muchos ofrecimientos de su hacienda y de dar orden como este testigo fuese vecino de este reino y hubiese unos indios". ${ }^{44}$ Es interesante notar cómo algo que era un soborno y una ilegalidad no fuese objeto de sobresalto en el interrogatorio. Posteriormente, Cartagena expuso que, la segunda noche después de ser nombrado, cerca de medianoche se presentó en su casa Marcos de Luzio, abogado de Santillán, para ofrecerle derechamente un soborno:

Luzio le dijo ciertas palabras de ofrecimiento que en efecto eran mostrando con este testigo amistad y mostrando tener voluntad de socorrer la necesidad en que este testigo a la sazón estaba y sacó del seno un tejo de oro que le parece a este testigo según el grandor que tenía a lo que le dijo que pesaría como mil pesos, los cuales le persuadió que tomase diciéndole que lo hacía de suyo sin que lo supiese Hernando de Santillán, porque pues era costumbre pagar en esta ciudad las asesorías

42 AGI Justicia 469, f. LXXI, 6 de enero de 1561.

43 AGI Justicia 401.

44 AGI Justicia 401. 
que aquello quería él que recibiese este testigo por el trabajo que había de tener en la vista y determinación de aquel pleito. A lo cual este testigo le respondió retrayéndole lo que hacía y dándole a entender que conocía que era de amistad y que confiado de aquello lo debía haber hecho, que se lo llevase a su casa que cuando este testigo tuviese necesidad se lo pediría. A lo cual él le tornó a responder que lo recibiese que otro día le traería otras ocho barras y este testigo por buenas palabras le hizo que se llevase el tejo de oro y se esimió (sic) del aquella noche y así se la llevó y otro día por la mañana este testigo fue a rogar al doctor Cuenca oidor que fuese a hablar al Marqués de Cañete para que le relevase de que no quería ser tercero en aquella causa y el dicho doctor Cuenca le preguntó la causa y este testigo se la dijo y él fue a hablar al dicho visorrey y pareció que le debió de decir lo que este testigo le dijo y así envió a llamar a este testigo y le preguntó la causa porque se quería eximir de aquel negocio y este testigo creyendo que no lo sabía le dijo que por el trabajo que era leer un negocio tan grande y de tanta pasión y entre personas tan ricas y le tornó a mandar que sin embargo lo viese y así este testigo queriéndose eximir le declaró lo que había pasado la noche antes y oído mandó a este testigo que se lo averiguase diciéndole en ello algunas palabras airadas y así tornó a llamar al doctor Cuenca y le debió de dar cuenta del negocio y salido este testigo dieron traza entre ambos a dos por la cual mandaron a este testigo tornándole a llamar para ello que en un aposento de su casa diese orden como oyesen dos personas del mismo licenciado Luzio lo que había pasado la noche antes y que uno de ellos había de ser el mayordomo del dicho marqués y así aquella noche u otra que no se acuerda bien fue a su posada de este testigo Montoya mayordomo del dicho Marqués el cual le dijo que el visorrey le enviaba para lo que le había mandado a este testigo y así lo metió juntamente con Francisco de Godoy que fue a Chile con Francisco de Aguirre en un aposento donde este testigo tenía su estudio en un hueco que tenía la pared tapado con esteras, y estando allí envió a llamar al dicho licenciado Luzio el cual vino y después de haber tratado cierto artículo del proceso le preguntó este testigo donde tenía el tejo de oro que le había traído y las barras y otras particularidades de que este testigo señaladamente no se acuerda por haber tanto que pasó a lo cual le respondió que en su casa en su escritorio lo tenía e otras cosas semejantes a esto, y visto lo que había declarado lo que este testigo pretendía se salió con él, y otro día el Marqués de Cańete visorrey juntamente con el dicho doctor Cuenca a lo que este testigo se quiere acordar tomaron su declaración a este testigo y al dicho Montoya y Francisco de Godoy al cual este testigo se refiere que pasó ante Juan Muñoz Rico, y si en algo contradijere esto a aquello o faltare no es su intento de se contradecir sino solamente de decir verdad y así lo protesta y esto es lo que pasó en el artículo que se le pregunta y no otra cosa porque ninguna otra persona le trató de le dar ni le prometió ninguna cosa. ${ }^{45}$

El intento de soborno por la parte de Santillán tuvo su contraparte en la de Lucas. En las declaraciones que el secretario Pedro de Avendaño dio en el interrogatorio de la visita de Briviesca de Muñatones el 18 de enero de 1561, entre muchas cosas testifica:

[...] entendió este testigo lo mismo y así lo ha oído decir a algunos abogados de la Audiencia que en el proceso que se trató entre Lucas Martínez vecino de Arequipa y Hernando de Santillán. Y al visorrey don Hurtado de Mendoza difunto oyó este testigo decir algunas veces que no le había parecido bien el voto que en él había dado el doctor Cuenca y que tenía sospecha por las diligencias que se hicieron que había habido algún cohecho y este testigo ha oído decir a Alonso Galleguillos vecino de Arequipa y a Francisco de Burgos estante en esta ciudad y a Ińigo de Bocanegra y a Antonio de Quevedo de

45 AGI, Justicia 469. 
cómo habían entendido que el dicho Lucas Martínez había dado al dicho doctor Cuenca cinco mil pesos $[\ldots]^{46}$

En las declaraciones que se tomaron podemos verificar que Francisco de Burgos era un testigo cuestionable; solo aparece porque Santillán supo que estaba en su casa una indígena que había sido criada de la señora Isabel de Ovalle, donde estaba Cuenca, y que había comentado que unas mestizas de la casa supieron que Lucas había enviado las barras al dicho Cuenca. Los otros, ya sabemos que poseían vínculos: Quevedo, Galleguillos y Bocanegra que era el mayordomo de Villegas. Puntualmente, Quevedo "sabe" del asunto porque se lo dijeron Galleguillos y Bocanegra y el propio secretario Avendaño. Incluso, comentaban que fue un tal Andrés de Arbieto quien prestó los 5 mil pesos en barras a Lucas. ${ }^{47} \mathrm{Ga}$ lleguillos efectivamente fue a Lima y declara el 30 de abril. ${ }^{48}$ Posteriormente, expone el propio Lucas Martínez el 16 de mayo, negando tajantemente haber sobornado a Cuenca. ${ }^{49}$

Para precisar, en los cargos que se le formularon a Cuenca no viene mencionado el cohecho de Lucas, de manera que se dio por un cargo no comprobado. El tema de las compensaciones, dádivas o sobornos que los oidores recibían de los litigantes por encomiendas o asuntos penales y políticos fue muy documentado durante la visita de la Audiencia que practicó Briviesca de Muńatones en 1561. Algunos ejemplos salen a luz de las pesquisas que el comendador mandó hacer a Cusco y Arequipa para documentar los cargos a los oidores Cuenca y Mercado de Peñalosa (Angeli, 2011). Juan de Peñalosa, corregidor de los Andes, dio a la mujer del doctor Cuenca una fuente y jarro de plata; lo mismo hizo con la mujer de Mercado.

En otro pleito que se siguió a Diego de Peralta, vecino de Arequipa y encomendero de Capachica, por la

46 AGI Justicia 469. Testimonio de Avendaño entre ff. CXXIIv-CLXVv, f. CXXX. Ya vimos antes que Cuenca había sido implicado en otro caso de soborno, como declaró Galleguillos en el caso del pleito que se siguió a Noguerol de Ulloa, f. CXXXIX.

47 AGI Justicia 472.

48 AGI Justicia 472, f. CCCVI.

49 AGI Justicia 472, CCCVIv. muerte de ochenta indios ahogados en una barca en el río, trascendió que el citado Cuenca había mandado hacer a estos indios cuatro reposteros figurados con escudos de armas, los cuales no fueron pagados. Mercado también recibió de Diego de los Ríos, vecino del Cusco un cofre de plata. Al mismo tiempo, escribió a Alonso Manuel de Anaya, que como señalamos era entonces corregidor en Trujillo, para que no ejecutase una provisión contra uno de los acusados en las alteraciones de Hernández Girón. Por su parte, Juan de la Torre, vecino de Arequipa, y Juan de Vargas, de La Paz, enviaron a dońa Isabel Sauzedo (Salcedo), la mujer de Mercado, mil pesos y tratando a la sazón pleitos criminales en la Audiencia. Mientras que el poderoso Alonso Álvarez de Hinojosa en el Cusco mandó al mismo un frasco de plata y otras piezas por valor de más de 500 pesos; en este caso, el encargado de llevar la plata fue un tal Falcón, cuñado del intrigante escribano Benito de la Peña que en todos los casos cusqueños era el testigo por el comisionado de Muńatones..$^{50}$ No figura en estos expedientes el caso de Lucas Martínez y Cuenca, ya que ambos dieron informaciones que pesaron más en la evaluación del propio Muñatones. Por el contrario, Luzio fue sancionado.

Las averiguaciones contra el licenciado Marcos Luzio se practicaron el 6 de febrero de $1561 .^{51}$ Lo acusaron, entre otras cosas, de que siendo abogado de la hija de Villegas y de Santillán, intentara sobornar a Cristóbal Ramírez de Cartagena, llevando un tejo de oro que valdría mil pesos, que le dio Juan de Mori, vecino de Huánuco y casado con una hermana de Santillán. Le ofrecieron además 2 mil pesos y que cumplirían hasta 5 mil por el valor de unas casas. Dicha oferta la rechazó Cartagena, dando aviso al virrey marqués de Cañete.

Pero el testimonio más contundente es el que dio el propio Cuenca. Al respecto señala que muerto el virrey, se supo que la información quedó entre sus papeles y las llaves las conservaba su confesor, fray Juan de Aguilar, y el licenciado Altamirano. Sobre estos misteriosos papeles se realizó una pesquisa y se

50 AGI Justicia 475, cargos a Cuenca y Mercado, f. 377378 .

51 Sobre los entretelones del intento de negocio de la encomienda y la participación del abogado Luzio, AGI Justicia 475, f. 187. 
hizo declarar a Altamirano y al licenciado Santillán. Altamirano dijo no tener ya las llaves aludidas. Santillán apuntó conocer el informe, pero que este no estaba firmado y arguye en favor de Luzio, diciendo que Cartagena era un hombre honesto y limpio, que si le ofreció el dinero fue por su trabajo en la vista de la causa y no para que diera su voto favorable a su sobrino. Y que si interesaba a alguien el voto, era a la nińa Villegas que estaba entonces en Arequipa, de manera que cuando leyó el informe, no le dio importancia a lo que decía, agregando que además había sido instigado por Cuenca, al que Cartagena informó del asunto.

Al final, Muñatones acusa a Luzio de haber querido sobornar a Cartagena. También de haber hecho desaparecer la información del virrey contra él, la cual se buscó sin éxito. Del mismo modo, se le acusó que haber querido realizar la misma práctica de corrupción al doctor Oliva, tercero en discordia en el pleito por los indios de Chuquibamba entre Alonso de Luque y Diego Bravo. Esa vez, obsequió vajilla de plata y candeleros. De la misma manera, procuró que Gaspar de Sotelo sobornase al doctor Saravia en cierta causa sobre los indios de Pomatambo entre los herederos de Tomás Vázquez y Rodrigo de Esquivel. Para el 9 de abril de 1561 fue acusado de otros cargos de malas prácticas, siendo incluso encarcelado con grilletes. ${ }^{52}$ Como era de suponer, Luzio presentó sus descargos, aduciendo el tema de las "asesorías". Expresa que se trata de una práctica que se efectúa en la Nueva España y otras Audiencias para resolver discordias entre vecinos. Niega haber tenido intenciones de corromper y manifiesta que "no es verosímil que tan poca cosa había de dar de cohecho para causa tan ardua y calificada el que quisiese corromper al juez" ${ }^{53}$ Lo mismo argumenta para el caso de Luque y Bravo, señalando que era un caso "de pueblo de indios de grandes dudas" y que de haberle hecho un ofrecimiento, algo que niega, era solo por su asesoría.

Pese a su leguleya defensa, Luzio fue condenado a tres años de suspensión y al pago de 2 mil pesos, teniendo por fiador a Gómez Caravantes de Mazuelas

52 AGI Justicia 475, f. 187.

53 AGI Justicia 475.
(Honores, 2012). ${ }^{54}$ En el intertanto, los esposos se querellaron contra Muńatones acusando al visitador de no haber admitido una querella que en la residencia del doctor Cuenca pusieron contra él, por haberlos despojado del repartimiento de Tarapacá y de más de 60 mil pesos de hacienda, oro, plata, ganados y otras cosas. Precisan que Muñatones era amigo de Cuenca y por eso evitó que presentaran la denuncia. Agregan que no dejó que Luzio abogase por la causa que había puesto el sobrino de Santillán, el cual se encontraba en la corte de Madrid para seguir su pleito. Ante dicha acusación, Muñatones respondió que a Luzio se le prohibió litigar "por ser un hombre de poco crédito y de pocas letras y muy arrojado en sus palabras y que no convenía que abogase ante él”, y que había otros trece abogados en la Audiencia para ver el caso contra Cuenca. ${ }^{55}$

Acto seguido, Santillán denuncia a Cartagena por haber sido abogado de Lucas Martínez en la corte cuando pleiteaba con Villegas, y luego como relator, acompañó al virrey marqués de Cañete para sentenciar el pleito a favor del encomendero Martínez. ${ }^{56}$ En contrapunto, Cartagena exhibió otra documentación que apoyaba su causa y cuestionaba la de Santillán. ${ }^{57}$ Son las censuras que pidió Lucas Martínez al arzobispo de Lima en julio de 1562, cuando ya se había establecido en esa ciudad para proteger sus intereses y seguir esta guerra judicial. Lucas quería averiguar los cohechos que se intentaron hacer para perjudicarlo en el pleito criminal por decir que anduvo de su voluntad con Gonzalo Pizarro, causa en la que fue despojado de los indios Carumas, Loa, Arica y Tarapacá que se dieron a Jerónimo de Villegas, perdiendo más de 40 mil pesos.

54 AGI Justicia 475, f. 238. Sobre Luzio, véase Honores (2012). En poco tiempo, Marcos de Luzio reclamó. AGI Escribanía 1007 A, 1564.

55 Hernando de Santillán y Ana de Villegas, vecinos de Arequipa, sobre repartimiento de indios, 1563, AGI Justicia 1059.

56 AGI Justicia 1060, Querella entre Hernando de Santillán y su mujer, Ana de Villegas, vecinos de Arequipa con el licenciado Cristóbal Ramírez de Cartagena, abogado, sobre que dé cuenta de cierta información de testigos que por los dichos se le había entregado y la ocultaba maliciosamente. Consejo año de 1564.

57 AGI Justicia 1060, f. CXLIIII. 
Existen nuevos datos sobre decidores parentescos que se delatan a partir de estos legajos. En el pleito entre Santillán y Cartagena, llevado adelante en Madrid desde la segunda mitad de 1563, figuran algunos antecedentes. ${ }^{58}$ Santillán explica que dejó a su mujer, la jovencita Ana de Villegas, en Huánuco con Juan de Mori (León, 2002, pp. 217-219), el mismo que dio dinero para el cohecho que se intentó con Cartagena y con Pedro de Villagrán (Villagra). No es menor que Juan y Pedro estuvieran casados nada menos que con las hermanas de Santillán, Leonor y Beatriz de Figueroa, viuda de Rodrigo de Pineda y Juan Tello su deudo (Glave, 2013).

\section{Esponsales y defunciones}

La defunción del capitán Jerónimo de Villegas abrió una nueva etapa en la lucha judicial de Lucas Martínez. Fue la configuración de una poderosa parte rival, sobre la base de la alianza entre el oidor Santillán y su sobrino, con Juan de la Torre -también encomendero en Arequipa e implicado en la asonada de Hernández Girón-, el tutor de la menor y articulador de sus negocios. Entre la documentación que archivó en la causa de residencia el comendador Muñatones se conserva la recusación que hizo Lucas Martínez del licenciado Hernando de Santillán, oidor, y de los abogados Marcos Luzio y el licenciado Guarnido. Se informa sobre la causa criminal que tratan contra él en la audiencia por la determinación del título solicitada para la hija de Villegas los indios que ha detentado y un pleito por trigo y maíz. ${ }^{59}$

Martínez los recusa por haber pactado el matrimonio de Ana con el sobrino del oidor, y donde estaban implicados Luzio, el tutor de la menor Juan de la Torre y Guarnido. De esta manera, Lucas Martínez se presentó en Lima el 1 de abril de 1555, instancia en la cual deposita como garantía para la recusación 30 mil maravedís en plata quintada con apoyo de Alonso de Valenzuela, vecino de Los Reyes. Por ello, gana derecho a llevar adelante la recusación y presenta preguntas para el interrogatorio.

En este, Lucas Martínez, que escribió de su puño y letra las preguntas, hizo parecer al tutor Juan de la

58 AGI Justicia 1060.

59 AGI Justicia 471, f. DCCCCXXXIIII.
Torre, al oidor Santillán y al propio Marcos Luzio, quienes sin escrúpulo dijeron que no habían concertado la boda. Luego, realiza un pliego de preguntas para probar que dos meses atrás se había ido Santillán a Arequipa con un tal Luis Dávalos de Ayala, enviados por el oidor y aviados por él para realizar el casamiento. Seguidamente, Juan de la Rua testifica que estando en Arequipa junto a Gómez de Solís y Gerónimo Costilla, supieron que Dávalos llegó y que de noche entró Santillán para realizar la boda. A la mañana siguiente ellos fueron a dar el parabién, y se encontraron después con "un Bocanegra" (como se refiere a Ińigo), el cual "se dice criado del dicho Jerónimo de Villegas e que entiende en sus haciendas" ${ }^{60}$ Ińigo, agregan, estaba muy enojado por la boda, por lo cual intentaron consolarlo. Otro testigo, el licenciado Gómez Fernández, apunta que la boda se realizó ante mucha gente y en casa de Hernando de Rivera y fue presidida por el propio obispo del Cusco. Insisten en que la boda se había realizado hacía un mes más o menos.

Sin embargo, en el expediente de la encomienda viene la probanza hecha en Huánuco en julio de 1558. ${ }^{61}$ De esta forma, sabemos que el matrimonio se realizó en junio de 1558, siendo celebrado el sacramento por el vicario mayor García Sánchez, actuando como padrino Martín de Guzmán. El mismo Santillán en la probanza que practicó en Madrid (1561) describe que primeramente en Arequipa el 11 de octubre de 1555 la desposó "por palabras de presente". Dos años después, la llevó a Lima a la casa de su tío el licenciado, donde vivieron como marido y mujer por más de un año, y luego la llevó a Huánuco, donde recibieron las bendiciones de la iglesia. ${ }^{62}$

Con el paso de los años, Santillán, escabullido siempre para no ser procesado, pasó a la corte real para continuar con el pleito. Allí siguió reclamando la encomienda, denunciando a Cartagena, a Cuenca y al propio Muñatones. Pronto recibió la compañía de su tío el oidor, que tuvo que ir a defenderse a los altos tribunales de las condenas que recibió de la visita de la Audiencia. Con ellos

60 AGI Justicia 475.

61 AGI Justicia 401, $N^{\circ} 1$, Segunda pieza, f. XL. im. $1747 / 147$.

62 AGI Justicia 401, f. CCLXI, im. 587, $2177 / 3225$. 
también terminó en Madrid el secretario Avendańo y el relator Cartagena.

Mientras tanto en Lima, Lucas Martínez quedó procurando rehacer su mermada economía. La relación de servicios de Hernando de Santillán pidiendo indios, consultada en Madrid a 17 de mayo de 1565 relata el proceso de encomiendas que siguió su familia hasta quedar sin nada. Al respecto consignemos que María Calderón gozaba del repartimiento de Garruchamba que había sido de Jorge Hernán$\mathrm{dez}$, su primer marido, al que los propios indígenas mataron. Muerta cruelmente también, junto con su pequeño hijo a manos de Francisco de Carvajal en el Cusco y habiendo servido su marido, Jerónimo de Villegas, La Gasca le dio el repartimiento de Arica y Tarapacá que gozó por ocho años, aunque como vimos, tuvo pleito con Lucas Martínez Vegaso. Muerto Jerónimo, sucedió Ana Villegas, mujer de Santillán, y perdieron en la Audiencia el repartimiento, apelaron y nuevamente perdieron también en el Consejo. Santillán incluso argumentó sus propios méritos al haber capturado a Toribio Galíndez de la Riva que quería apoyar a Girón y luego fue a dar auxilio a Desaguadero al capitán Gómez de Solís que impedía que Girón pasara a Charcas a robar los reales quintos. Por los servicios de sus suegros que no tenían retribución al perderse Tarapacá y por los suyos propios, pidió un repartimiento, como fue Parinacocha que vacó por muerte de Alonso Álvarez de Hinojosa o el de los Collaguas, que fue de Francisco Noguerol de Ulloa, quien se encontraba en España. En síntesis, y con todo este laberinto de situaciones y relaciones múltiples de poder, Lucas había ganado. ${ }^{63}$

Empieza entonces el último capítulo de la historia de la encomienda. A principios de mayo de 1567 tuvo lugar otro enfrentamiento de intereses a propósito de los indios de Tarapacá y Arica. El martes 29 de abril, Lucas Martínez fallece en Lima. De inmediato, el licenciado de Monzón pidió justicia en nombre del rey diciendo que la encomienda había quedado vacante, pues el fallecido no había dejado ni hijos ni legítima mujer. Cuando Álvaro Ruiz de Navamuel, secretario de cámara, notificó el pedimento y notificación por parte del gobernador Lope

63 AGI Lima 121. Expediente Santillán.
García de Castro, el 7 de mayo aparece en escena la joven María Dávalos contradiciendo el pedido de Monzón. María señala que el mismo fiscal, como todos en la ciudad, sabía que ella se había casado legítimamente con Martínez y, por lo cual, era la sucesora de los indios. Incluso, agrega María Dávalos, el propio Monzón había ido personalmente acompańado del licenciado Francisco Falcón, abogado de la Audiencia, a darles los parabienes a los flamantes esposos cuando se desposaron.

Tras emplazar al fiscal, la viuda de Martínez pone por testigos del casamiento a un elenco en el que destaca el entonces alcalde ordinario Gómez de Caravantes y nada menos que a un conspicuo de las guerras civiles y la implantación del Estado colonial, Gil Ramírez Dávalos. Conjuntamente, habrían sido testigos Álvaro de Torres, Diego López de Zúñiga, el escribano Juan de Padilla y el clérigo Rodrigo Prieto, entre otras personas. El gobernador entonces remitió el expediente por ser negocio de justicia al tribunal de la Audiencia y así se inaugura un nuevo caso por la sucesión que terminó beneficiando a la joven Dávalos, hija de Nicolás de Rivera "el Viejo". ${ }^{64}$

Tal como lo hizo el fiscal Monzón, también rápidamente se generaron reacciones. En el valle de Ica, en el tambo de Ucarcana, el viernes 2 de mayo Diego de Lerma, un representante de María Dávalos, había tomado posesión en nombre de la viuda de dos indios que iban a ver a Lucas Martínez. Se trataba de un principal de Carumas, Hernando Cayastiti y otro de Tarapacá llamado Alonso Lucaya. Diego de Lerma llevaba un poder de María Dávalos, el certificado de la muerte de Lucas Martínez, otro de su matrimonio y las cédulas atenientes a la manera de suceder los indios; todos estos documentos se los llevó a Arequipa una vez que tomó posesión de los dos principales interceptados en el camino a Lima, a quienes también llevó de vuelta a casa.

Ya en Arequipa, fue el capitán Gerónimo de Zurbano quien presentó los papeles referidos para representar a María Dávalos. ${ }^{65}$ Esta vez, los esponsales "por palabras de presente" como carta ganadora, la jugó en su lecho de muerte Lucas Martínez Vegaso,

64 AGI Justicia $443 \mathrm{~N}^{\circ} 1$, R. 2.

65 AGI Justicia 401, Im. 56/53. 
para que su encomienda le granjease un capital con el cual poder pagar sus deudas y dejar una herencia generosa a muchos de sus allegados y familiares. Tal como hemos constatado, ciertamente lo que intentó Santillán para ganar la mano, le sirvió a Martínez para doblársela tras su muerte.

El 12 de mayo de 1567 el contador Hernando de Almonte también intentó acceder a la posesión de los indios de Lucas Martínez por estar vacos. No obstante, Zurbano contradiciendo dicha intromisión expone que ya había tomado posesión de los indios como sucesora María Dávalos. A pesar de ello, Almonte tomó posesión de un indio de Carumas y por él de los indios de ese repartimiento y de los de Arica y Tarapacá. Sigue la contradicción que por supuesto presentó Zurbano. El argumento principal de este, que tomó posesión con autoridad del alcalde ordinario de la ciudad, es que su ceremonia se celebró antes, más temprano el mismo día que la posesión que el contador tomó con anuencia del corregidor. Luego, el fiscal Monzón vuelve a alegar que los indios son vacos y añade detalles en detrimento de la causa de Dávalos. Argumenta que se casaron con prisa, sin las amonestaciones públicas requeridas, estando incluso Lucas en pie de morir. Declaran que habían entregado para que Lucas disponga libremente aunque muriese, de 16 mil pesos como si fuera dote, por lo que "pareció y se entendió ser más venta de indios" con claros ribetes de fraude. Abunda el fiscal que cuando todavía Lucas Martínez caminaba, estuvo tratando el precio de la dote. Aún más, añade como una determinación de los comisarios acerca de la sucesión que declaraba que debían vivir las mujeres que se casaran con los maridos por lo menos 20 días, pero en este caso, Lucas murió solo a los 10 días.

Las ceremonias matrimoniales, como sabemos, tenían gran importancia en la naciente sociedad colonial. La presteza y celeridad de la actuación de la nueva parte interesada que sucedía a Martínez determinó su éxito. Pero desde luego, no fue lo único; las redes de poder del clan del conquistador Nicolás de Rivera garantizaron el negocio. Le conceden así a María Dávalos que reciba los tributos mientras se determina la causa. En este escenario jugó un rol significativo, aparte del "mozo" hijo del viejo Nicolás,
Lorenzo Estopiñán de Figueroa, su yerno. Esta vez, la parte del poderoso grupo de los descendientes de Ribera logró quedarse con la encomienda. La historia, al parecer, había concluido.

\section{Reflexiones finales}

Los múltiples personajes que hemos retratado en su actuación concreta en las escenas de la temprana vida colonial, interactuando en un escenario geográfico relativamente marginal -pero muy articulado con los centros dinamizadores- nos ilustran la trama del poder del naciente virreinato peruano. Los distintos estamentos, las encontradas y complejas relaciones entre personajes que encarnaban amplias redes sociales, se enfrentaban y resolvían sus diferendos en el anfiteatro administrativo que fue la Audiencia. Esta se encargaba de fomentar y administrar "luchas de competencia entre diversas estructuras de autoridad" que terminaron "configurando un complejo equilibrio de tensiones" (Bridikhina, 2007, p. 17). ${ }^{66}$

Aunque muy temprano todavía, en la maduración de un orden colonial (Sánchez, 1960; Bakewell, 1989), ${ }^{67}$ este estudio de la resolución de tensiones de poder que enfrentaron redes de interrelaciones muestra que ya se configuraba una estructura atlántica que vinculaba los Andes y América con la corte real, haciendo del binomio Consejo de Indias-Real Audiencia una realidad que permitía tempranamente que todos aceptaran que se cumplía la ley: "la gente teme ya y respeta la justicia", escribía al rey Pedro de La Gasca al "pacificar" el reino (Angeli, 2007).

Los oidores de la Audiencia modelaron con su evidente influencia una sociedad donde la complicidad entre poder político, poder económico y líneas parentales era imprescindible para gobernar y para

66 Bridikhina (2007) adapta los conceptos e ideas de Norbert Elías sobre la sociedad cortesana. Si bien no trata esta época, sus sugerencias son significativas para el contexto.

67 Bakewell (1989) se basa en el legajo de AGI Lima 92 y Lima $28^{\mathrm{a}}$, concentrándose en el período inmediatamente posterior al analizado en este artículo. Sánchez (1960), por su parte, usa otra información a la ilustrada por Bakewell, y desarrolla críticas hechas por funcionarios al gobierno del marqués de Cañete. 
fomentar el patrimonio; si faltaba uno, caía el otro. En un escenario tal, la lucha por controlar las encomiendas, todavía el centro de la riqueza, tuvo que ser encarnizada y contradictoria, como se ha constatado con una serie de variados detalles que hemos expuesto in extenso. Al depender el control de una "merced" de suma fragilidad y cambiantes restricciones de la interpretación de la ley por los jueces, que eran ellos mismos la justicia, la línea divisoria entre redes de poder familiares y de afinidades particulares, y el ejercicio de la justicia real encarnada en los oidores, era muy tenue y se cruzaba fácilmente entre sí. Controlar aquel poder inmenso de los jueces de la chancillería real, tan lejos de la corte peninsular y el rey, fue uno de los principales objetivos de la legislación colonial. En ese contexto, se llevaron adelante las visitas, y particularmente, la de 1561 que hemos analizado detenidamente.

Estamos en los albores de una práctica judicial propiamente indiana, el gobierno de reinos muy lejanos a la figura del rey en sociedades de antiguo régimen, donde el ejercicio del poder estaba marcado por la existencia de linajes, paisanaje, patronales y clientelares que circulaban en un laberinto de relaciones de poder. Como ya vimos, surgen tanto los preceptos como la práctica asociada a ellos, que luego, al cabo de varias décadas, darán origen al derecho indiano, con sus leyes, su práctica judicial y su orden administrativo.

Ese es el plasma generador de los documentos judiciales examinados, con todas sus ramificaciones y aplicaciones en el tribunal audiencial y en el del corregidor y los comisionados de campo. Incluso, en su trasvase al tribunal supremo del Consejo de Indias. Dichos materiales los hemos entendido en un marco más amplio, que no se ha desprendido de lo institucional -el contexto de la visita y residencia a los funcionarios del rey y a los letrados- y lo que atańe al surgimiento de una forma de Estado y gobierno (la práctica del ejercicio de gobierno por la Audiencia, las relaciones con el virrey y con las autoridades locales o los comisionados de campo). Pero, fundamentalmente hemos presentado el entablado social de la época, atendiendo a las redes de poder en las regiones, las familias, las pugnas y las jerarquías sociales que se formaban, llenas de confusas contradicciones. El derecho como código y práctica era solo una parte del universo jurídico que se conformaba en un complejo tejido con la moral, las jerarquías y las familias o casas señoriales, en una sociedad marcada por las fidelidades, las amistades, los padrinos y los clientes, que hacían del ejercicio de la justicia colonial una pieza del engranaje creador de nuevas formas de relaciones sociales (Hespanha, 1989).

En ese sentido compartimos la visión que tiene Angeli (2013) después de evaluar la documentación de la visita de la Audiencia que practicó Briviesca de Muńatones:

La visita del licenciado Diego Briviesca de Muñatones a la Audiencia de Lima mostró las dos caras del tribunal limeńo. La investigación sobre el funcionamiento de la Audiencia evidenció las prácticas de favoritismos, arbitrariedades, manejos discrecionales y pujas de poderes que realizaron ciertos oidores como hombres fuertes de un débil e incipiente virreinato, anteponiendo la "persona privada" a la "persona pública" del magistrado, a fin de sortear responsabilidades y acumular honores y patrimonio. Sabedores de la alta estima con la que contaban y fuertes manipuladores de las camarillas internas de la sociedad hispano-peruana, varios ministros limeños se dejaron seducir más por sus "pasiones" que ennoblecer su función con el recto obrar de sus "virtudes" por las que tanto bregaba la Monarquía católica. La investigación del juez visitador logró recopilar toda la información necesaria para demostrar cómo la "recta justicia" que se debía impartir fue, en varias ocasiones, trastocada y utilizada en favor de los magistrados (Angeli, 2013, p. 24).

Sin embargo, ninguno fue condenado por nada, aunque alguno tuvo que bregar y mover sus influencias en el tribunal supremo de Madrid para salvar su puesto, su carrera, su hacienda y su reputación. Siguiendo a Tau Anzoátegui, Angeli (2013) concluye que "La Monarquía católica llevó adelante la tolerancia y la disimulación como formas legítimas de sostener un sistema que buscaba equilibrar antes 
que derribar los consensos estipulados por la tradición" (p. 26).

Hemos llegado a las altas esferas del gobierno virreinal naciente, pero partimos en los arenales del sur andino tarapaqueño, del antiguo Colesuyo, donde reinó, fue destronado y restituido un conquistador paradigmático.

Buscando a Lucas Martínez Vegaso, un modesto funcionario que obedecía la orden del juez de jueces y llevó a la base regional las pesquisas que debían determinar si la marcha de la justicia real obedecía a los objetivos de la monarquía, nos ha permitido encontrar el hilo conductor entre la realidad más local y el entramado más complejo y global de la formación de un orden imperial: un gobierno de la justicia que encarnaba al rey y unas instituciones gubernativas que permitieron la consolidación del orden colonial en los Andes.

\section{Agradecimientos}

A los evaluadores del manuscrito original y a los proyectos FONDECYT 1181844 y UTA Mayor 5767-18. Se agradece al Convenio de Desempeño UTA - MINEDUC, que permitió desarrollar las labores de pesquisa y análisis documental.

\section{Referencias citadas}

Angeli, S. (2007). "La gente teme ya y respeta a la justicia”: Oidores y Audiencia en el siglo XVI peruano. En Primeras jornadas nacionales de historia social. Córdoba: La Falda.

Angeli, S. (2011). "Dime con que varas juzgas y te diré tu patrimonio": El licenciado Pedro Mercado de Peńalosa, oidor de la Audiencia de Lima (1553-1562). Anuario del Centro de Estudios Históricos "Prof. Carlos S. A. Segreti", 11, 131-151.

Angeli, S. (2013). “¿Buenos e rectos jueces?”: La visita a la Audiencia de Lima por el licenciado Briviesca de Muñatones, 1560-1563. Jahrbuch für geschichte lateinamerikas. Anuario de historia de América Latina, 50, 9-29.
Álvarez, B. (1588 [1998]). De las Costumbres y Conversión de los Indios del Perú. Memorial a Felipe II. Madrid: Ediciones Polifemo.

Bakewell, P. (1989). La maduración del gobierno del Perú en la década de 1560. Historia Méxicana, XXXIX(1), 41-70.

Barnadas, J. (1973). Charcas, orígenes históricos de una sociedad colonial. La Paz: Centro de Investigaciones y Promoción del Campesinado.

Bertonio, L. (1612). Vocabulario de la lengua aymara. La Paz: CERES - IFEA - MUSEF.

Bridikhina, E. (2007). Theatrum mundi. Entramados del poder en Charcas colonial. La Paz: Plural -IFEA.

Cerrón Palomino, R. (1998). Examen de la teoría aimarista de Uhle. En Max Uhle y el Perú Antiguo. Lima: Fondo Editorial de la Pontificia Universidad Católica del Perú.

Coello, A. (2002). Resistencia e integración en la Lima colonial. El caso de la reducción de indios de El Cercado de Lima (1564-1567). Revista Andina, 35, 111-128.

Cook, A. y Cook, N. (1991). Good faith and truthful ignorance. A case of transatlantic bigamy. Durham: Duke University Press.

De la Puente, J. (1992). Encomienda y encomenderos en el Perú: estudio social y político de una institución colonial. Sevilla: Diputación Provincial de Sevilla.

Díaz, A. (2003). Sibaya. Historia de una comunidad andina en la precordillera de Tarapacá. Iquique: Programa Orígenes.

Díaz, A., Ruz, R. y Galdames, L. (2013). Y llegaron con cadenas. Los afrodescendientes en la historia de Arica y Tarapacá. Siglo XVI-XIX. Arica: Ediciones Universidad de Tarapacá.

Díaz, A., Martínez, P. y Ponce, C. (2014). Cofradías de Arica y Tarapacá en los siglos XVIII y XIX. Indígenas andinos, sistema de cargos religiosos y festividades. Revista de Indias, 74(260), 101-128.

Donoso, C. (2008). Prosperidad y decadencia del mineral de Huantajaya: una aproximación. Diálogo Andino, 32, 59-70. 
Galdós, G. (1987). Comunidades prehispánicas de Arequipa. Arequipa: Fundación M. J. Bustamante de la Fuente.

Gavira, M. (2005). Producción de plata en el mineral de San Agustín de Huantajaya (Chile), 1750-1804. Chungara. Revista de Antropología Chilena, 37(1), 37-57.

Glave, L. (2013). El quipu que los indios de Parinacocha presentaron al licenciado Polo. En El quipu colonial. Estudios y materiales (pp. 283-306). Lima: Pontificia Universidad Católica del Perú.

Hanke, L. (1978). Los virreyes españoles en América durante el gobierno de la Casa de Austria. Madrid: Biblioteca de Autores Españoles.

Hespanha, A. (1989). Visperas del Leviatán. Instituciones y poder politico (Portugal, siglo XVII). Madrid: Taurus.

Hidalgo, J. (2004). Historia Andina en Chile. Santiago: Editorial Universitaria.

Hidalgo, J. (2009). Corregidores ilustrados en el desierto de Arica, Tarapacá y Atacama, 1760 - 1780. Boletín de la Academia Chilena de la Historia, 118, 91-155.

Honores, R. (2012). Corrupción letrada en la Audiencia de Lima. El licenciado Marcos de Lucio y la visita de 1561. Manicomio Suyay, 1, 46-53.

Jiménez de la Espada, M. (1965). Relaciones Geográficas de Indias. Madrid: Biblioteca de Autores Españoles.

León, M. (2002). Paños e hidalguía. Encomenderos y sociedad colonial en Huánuco. Lima: Instituto de Estudios Peruanos.

Levillier, R. (1922). Audiencia de Lima. Correspondencia de presidentes y oidores, 1549-1564. Madrid: Biblioteca del Congreso Argentino.

Lisson, E. (1944). La iglesia de España en el Perú. Sevilla: Colección de Documentos.

Lockhart, J. (1972). Los de Cajamarca. Un estudio social y biográfico de los primeros conquistadores del Perú. Lima: Editorial Milla Batres.

Lockhart, J. (1982). El mundo hispanoperuano, 1532-1560. México D.F.: Fondo de Cultura Económica.
Málaga, A. (2013). Estudios históricos de Arequipa. Arequipa: Gobierno Regional de Arequipa - Cuzzi Editores.

Martínez, S. (1936). Fundadores de Arequipa. Arequipa: Tipografía La Luz.

Mukerjee, A. (2008). La negociación de un compromiso: la mita de las minas de plata de San Agustín de Huantajaya, Tarapacá, Perú (1756-1766). Bulletin de l'Institut Français d'Études Andines, 37, 217-225.

Presta, A. (2000). Encomienda, familia y negocios en Charcas colonial. Los encomenderos de La Plata 1550-1600. Lima: Instituto de Estudios Peruanos.

Sánchez, I. (1960). El gobierno del Perú 1556-1564. Anuario de Estudios Americanos, XVII, 408-524.

Torero, A. (2002). Idiomas de los Andes. Lingüistica e historia. Lima: Instituto Francés de Estudios Andinos.

Trelles, E. (1983). Lucas Martinez Vegazo: funcionamiento de una encomienda peruana inicial. Lima: Pontificia Universidad Católica del Perú.

Trelles, E. (1988). El testamento de Lucas Martínez Vegazo. Historia, 23, 267-293.

Villalobos, S. (1979). La economía de un desierto. Tarapacá durante la Colonia. Santiago: Ediciones Nueva Universidad.

Villalobos, S. (1985). Documentos sobre los negocios de los conquistadores. Historia, 20, 363-423.

\section{Archivos revisados}

Archivo General de Indias (AGI) Escribanía

AGI Indiferente

AGI Justicia

AGI Lima

AGI Patronato 